\title{
STUDI PENGGUNAAN MEDIA SIMULASI PhET DALAM PEMBELAJARAN FISIKA
}

\author{
F. Verdian ${ }^{1 *}$, M.A. Jadid ${ }^{1}$, M.N. Rahmani ${ }^{1}$ \\ ${ }^{1}$ Program Studi Pendidikan Fisika, Fakultas Ilmu Tarbiyah dan Keguruan \\ Universitas Islam Negeri Syarif Hidayatullah Jakarta, Indonesia \\ Jl. Raya Juanda No. 52A, Tangerang Selatan. \\ E-mail: fhemy.verdian18@mhs.uinjkt.ac.id
}

\begin{abstract}
Abstrak
Fisika dengan berbagai konsep yang masih sulit dipahami, memerlukan sebuah media pembelajaran yang mampu menjelaskan konsep tersebut dengan lebih mudah dan menarik. Keterbatasan media nyata menjadi kendala dalam melaksanakan pembelajaran virtual, sehingga guru membutuhkan media digital sebagai alternatif, salah satunya media simulasi PhET. Tujuan penelitian ini yaitu; 1) Mendeskripsikan penggunaan Simulasi PhET. 2) Mengetahui keefektifan penggunaan media Simulasi PhET dalam pembelajaran Fisika. 3) Mengetahui Kelebihan dan Kekurangan penggunaan Simulasi PhET dalam pembelajaran Fisika. Penelitian ini menggunakan penelitian deskriptif kualitatif dengan jenis Studi Kepustakaan. Hasil yang diperoleh menyatakan bahwa PhET merupakan aplikasi web base learning dengan berbagai materi yang memiliki kemudahan penggunaan serta mampu menjelaskan konsep melalui animasi simulasi dan penggunaan simulasi PhET akan lebih baik jika dikombinasikan dengan strategi pembelajaran yang berorientasi pada siswa. PhET memiliki kelebihan dan kekurangan. Salah satu kelebihannya ialah, efektif digunakan untuk menjelaskan konsep fisika yang bersifat abstrak.
\end{abstract}

Kata kunci: Efektivitas; PhET Simmulation; Physics

\section{Pendahuluan}

Pesatnya perkembangan teknologi berdampak pada segala aspek kehidupan, salah satunya pendidikan. Dalam bidang pendidikan, perkembangan teknologi berpengaruh pada penggunaan media pembelajaran. Berbagai media pembelajaran berkembang dan bertransformasi menjadi media berbasis digital. Media pembelajaran berbasis digital ini dapat berupa Learning Management system ataupun berupa animasi yang menggambarkan sebuah simulasi dari konsep pembelajaran.

Disisi lain kasus COVID-19 masih berlangsung secara global. Sehingga, berdampak juga terhadap penggunaan media Pembelajaran. Dengan adanya pandemi seperti saat ini, segala aspek dituntut untuk dapat memanfaatkan teknologi sebagai alternatif dalam pelaksanaan kegiatan dari berbagai bidang tidak terkecuali pendidikan. Hal ini selaras dengan pernyataan Menteri Pendidikan Nadiem Anwar Makarim, B.A., M.B.A dalam acara Hardiknas 2020 pada segmen "Belajar Dari COVID-19" melalui streaming Youtube yang menyebutkan bahwa dalam rangka digitalisasi berbagai hal, Teknologi dapat menjadi katalis yang mampu memperkuat guru dalam melaksanakan pembelajaran dengan baik dan bukan sebagai pengganti guru dalam melaksanakan pembelajaran. Dengan demikian, media pembelajaran memiliki peran penting dalam terlaksananya pembelajaran masa kini (Ghivarianto, 2020). 
Fisika memiliki momok pelajaran yang sulit dalam benak Sebagian besar siswa. Dalam pelaksanaannya, siswa harus melakukan kegiatan praktikum atau demonstrasi untuk memahami konsep secara riil. Terdapat berbagai hambatan dalam mencapai hasil belajar yang diinginkan. Pengelolaan laboratorium fisika yang belum efisien menjadi salah satu hambatan tersebut. Kondisi ini diperkuat oleh hasil survei terhadap guruguru fisika di MGMP Fisika Kabupaten Serang, bahwa hanya setengah dari guru yang melaksanakan praktikum untuk tiap materi pelajaran, yaitu $52,4 \%$ dan $47,6 \%$ guru menjelaskan kurangnya sarana dan prasarana yang dapat di gunakan untuk praktikum. Dan juga kurangnya sumber daya manusia dalam mengelola laboratorium menjadi hambatan dalam pembelajaran (Bhakti, Dwi, \& Dasmo, 2019).

Media pembelajaran berbasis digital telah berkembang dan berperan dalam proses pembelajaran fisika salah satunya berupa laboratorium virtual. Laboratorium virtual ini merupakan multimedia interaktif dengan serangkaian peralatan laboratorium dalam bentuk perangkat lunak (virtual), yang dioperasikan menggunakan perangkat keras komputer (riil) dan dapat melakukan simulasi layaknya kegiatan praktikum yang sebenarnya (Santoso, 2009). Salah satu laboratorium virtual yang digunakan secara global adalah simulasi PhET, yang dikembangkan oleh Universitas Colorado.

PhET menjadi pilihan banyak guru dalam melaksanakan praktikum virtual fisika karena memiliki akses gratis dan juga User Interface yang mudah digunakan. Kefleksibelan PhET juga menjadikannya simulasi yang portable, karena dapat diakses menggunakan berbagai device. PhET menyediakan simulasi berbasis animasi interaktif dari berbagai materi pembelajaran Fisika, Kimia, Biologi, Matematika dan Ilmu Kebumian sehingga memungkinkan siswa berinteraksi, serta mengeksplorasi pemahamannya pada materi yang dipelajari melalui simulasi tersebut. PhET mampu menghubungkan antara konsep dan fenomena riil yang terjadi serta memberikan gambaran visual terhadap fenomena yang sulit diamati oleh siswa secara langsung (Perkins et al., 2006).

Berdasarkan paparan tersebut, Penelitian ini mengangkat judul "Studi Penggunaan Media Simulasi PhET Dalam Pembelajaran Fisika". Adapun, tujuan penelitian ini adalah 1) Mendeskripsikan penggunaan Simulasi PhET. 2) Mengetahui keefektifan penggunaan media Simulasi PhET dalam pembelajaran Fisika. 3) Mengetahui Kelebihan dan Kekurangan penggunaan Simulasi PhET dalam pembelajaran Fisika.

\section{Metodologi}

Penelitian ini termasuk kedalam penelitian deskriptif kualitatif dengan menggunakan penelitian jenis studi kepustakaan. Studi kepustakaan merupakan sebuah metode pengumpulan data pustaka membaca, mencatat, hingga mengolah bahan penelitian yang sumbernya berupa buku ilmiah, karya tulis ilmiah, ensiklopedia, dan sumber tertulis lainnya baik tertulis maupun digital. Sugiyono (2010) juga mengatakan bahwa Studi Kepustakaan mencakup literatur teoritis, literatur ilmiah, serta referensi lainnya yang terkait budaya dan norma yang muncul di lingkungan sosial yang sedang diteliti. Adapun langkah-langkah dalam penelitian studi kepustakaan menurut Kuhltau (2002) antara lain; 1) Memilih Topik Penelitian 2) Mengeksplorasi Informasi Yang Terkait, 3) Menentukan Topik Penelitian, 4) Mengumpulkan Berbagai Sumber Data, 5) Melakukan Persiapan Dalam Penyajian Data, 6) Menyusun Hasil Penelitian. Pada penelitian ini, pengumpulan data penelitian menggunakan sumber dari artikel-artikel pada jurnal Nasional dan Internasional.

\section{Hasil dan Pembahasan}

$\mathrm{PhET}$ merupakan sebuah aplikasi berbasis website yang memuat simulasi dari berbagai konsep fisika. Dengan simulasi, PhET dapat melakukan berbagai kegiatan eksperimen yang tidak dapat dilakukan secara riil. Media simulasi PhET dapat diakses secara gratis melalui website https://phet.colorado.edu oleh pendidik maupun peserta didik. PhET dapat digunakan melalui komputer, maupun melalui browser android, hingga 
dikombinasikan dalam sebuah aplikasi lain seperti PowerPoint, Aplikasi Android, ataupun Nearpod dan lainnya. Dikarenakan simulasi PhET berbasis HTML.

PhET merupakan aplikasi yang mudah digunakan karena memiliki user interface yang sederhana. Pengguna cukup menyiapkan komputer maupun smartphone untuk membuka website PhET. Selanjutnya, pilih materi yang ingin disimulasikan kemudian operasikan sesuai dengan materi simulasi. Dengan kemudahan tersebut $\mathrm{PhET}$ banyak digunakan sebagai alternatif atas minimnya peralatan laboratorium.

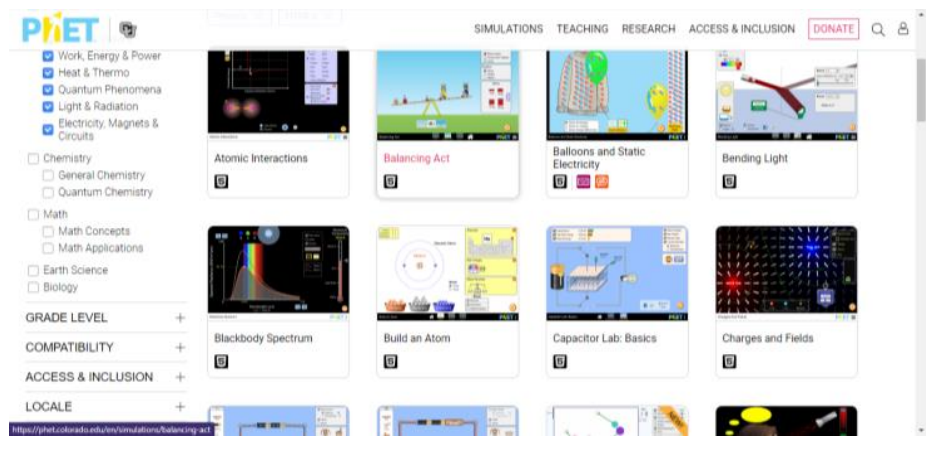

Gambar 1. Tampilan awal PhET

Media simulasi PhET sangat membantu guru dalam menyampaikan berbagai konsep fisika melalui simulasi interaktif. Dengan menampilkan berbagai fenomena yang tidak dapat diamati secara langsung, dapat meningkatkan ketertarikan dan rasa ingin tahu siswa. Hal tersebut sejalan dengan pendapat Perkins et al., (2006) yang menyarankan menggunakan pendekatan inkuiri terbimbing, sehingga efektivitas penggunaan PhET menjadi lebih baik. Penelitian yang mendukung pendapat tersebut telah dilakukan oleh Azizaturredha, Fatmawati, \& Yuliani (2019) menjelaskan bahwa hasil belajar, keterampilan proses sains dan minat belajar siswa akan meningkat Ketika menggunakan PhET dan model pembelajaran inkuiri terbimbing. Hal tersebut dikarenakan pembelajaran inkuiri terbimbing mampu membangun pengetahuan siswa berdasarkan pengalaman langsung menggunakan media simulasi PhET. Selain itu, media simulasi PhET memiliki ilustrasi yang menarik dan menyenangkan serta mampu menumbuhkan minat belajar lebih tinggi.

Media simulasi PhET tidak hanya digunakan menggunakan model pembelajaran inkuiri terbimbing, akan tetapi dapat menggunakan berbagai model pembelajaran lainnya. Sebagaimana penelitian yang dilakukan oleh Eveline, Jumadi, Wilujeng, \& Kuswanto (2019) memiliki hasil bahwa pendekatan Scaffolding berbantuan simulasi PhET dapat meningkatkan kemandirian siswa dalam belajar. Dimana, siswa menjadi lebih aktif ketika mencari ilmu dan berinteraksi sesama siswa selama proses pembelajaran. Begitu pula dengan penelitian yang dilakukan oleh Laila (2020) menjelaskan tentang penerapan laboratorium virtual berbasis STEM dapat meningkatkan keterampilan penyelesaian masalah. Keterampilan penyelesaian masalah tersebut yaitu kemampuan siswa dalam menemukan sebuah solusi dengan cara memperoleh dan mengorganisasikan sebuah informasi melalui laboratorium virtual berupa media simulasi PhET. Selanjutnya, berdasarkan hasil penelitian Aprilia, Rustana, \& Budi (2020) membuktikan bahwa pemanfaatan media virtual PhET ketika pembelajaran jarak jauh yang dilakukan menggunakan Zoom dapat meningkatkan kemampuan HOTS siswa SMA dengan kategori sedang.

Berdasarkan penelitian Maulina \& Kustijono (2017) mendapatkan hasil bahwa pembelajaran menggunakan media PhET lebih efektif dalam praktik daripada mengandalkan praktikum nyata. Karena media visual memungkinkan siswa untuk lebih aktif merepresentasikan materi yang dipelajarinya. Dan juga memungkinkan guru untuk lebih mudah memberikan makna dan bentuk pembelajaran yang disampaikan. Hal ini sejalan dengan pendapat Muzana, Lubis, \& Wirda (2021) bahwa dengan menggunakan simulasi PhET membuat siswa lebih aktif dan antusias mengikuti pembelajaran, karena media simulasi PhET ini memiliki tampilan yang unik dan menarik. Berdasarkan penelitian tersebut, hasil belajar siswa yang 
menggunakan simulasi PhET mengalami peningkatan yang lebih tinggi dan dapat meningkatkan kemampuan berpikir kritis siswa.

Sedangkan menurut Ramadhan, Hasyim, \& Wibowo (2019) pembelajaran dengan media PhET dan demonstrasi sederhana lebih efektif dibandingkan pembelajaran konvensional dengan media papan tulis. Hal ini berdasarkan respons siswa bahwa pembelajaran berbasis media PhET merupakan hal yang baru, juga dapat memudahkan siswa dalam memvisualisasikan materi pelajaran, menciptakan pengetahuan yang lebih dalam dan meningkatkan motivasi belajar. Efektivitas yang tinggi dalam pembelajaran dengan media PhET dan demonstrasi sederhana dikarenakan pengaruhnya terhadap minat belajar dan hasil belajar yang signifikan, maka pemilihan media dan teknik pengajaran harus sesuai.

Selain itu, setiap media pastilah memiliki kelebihan dan kekurangannya tersendiri. Sehingga perlu adanya pengembangan dari media tersebut untuk menyesuaikan dengan berkembangnya zaman serta menyempurnakan kekurangan dari tiap media. PhET pun demikian, terdapat kelebihan dan kekurangan yang saling melengkapi di dalamnya. Kelebihan dari penggunaan PhET ini adalah memiliki akses gratis sehingga siapapun dapat mengaksesnya, kemudian berbasis website yang memudahkan pengguna mengakses melalui berbagai perangkat, serta tampilan pengguna yang sederhana, sehingga membuat guru maupun siswa dapat dengan mudah mengoperasikan simulasi. Pernyataan tersebut selaras dengan hasil temuan yang dilakukan oleh Muzana et al. (2021) terkait dengan kelebihan penggunaan PhET dalam pembelajaran. Dalam penjelasannya, PhET merupakan media pembelajaran efektif dan dapat meningkatkan kemampuan ICT literasi siswa. Karena kemudahan penggunaan PhET, media simulasi ini dapat digunakan secara mandiri tanpa harus diawasi guru.

Kelebihan penggunaan PhET lainnya yakni mampu memberi gambaran fenomena abstrak dalam fisika yang sulit diobservasi langsung oleh indera manusia menjadi mungkin dengan simulasi (Sari et al., 2021). Meskipun penggunaan PhET yang sederhana dan fleksibel, simulasi ini tetap memperhatikan aspek kognitif yang menjadi inti dalam pembelajaran. Kesesuaian antara konsep dan aplikasi berbanding lurus sehingga tidak akan terjadi miskonsepsi dalam pembelajaran (Dasmo, Budi Bhakti, \& Napis, 2020).

Disisi lain, PhET sebagai media pembelajaran juga memiliki beberapa keterbatasan penggunaan yaitu perlunya perangkat elektronik seperti smartphone, komputer dan sebagainya. Juga masih perlunya peningkatan kemampuan guru menjalankan simulasi dalam pembelajaran di kelas (Ben Ouahi, Ait Hou, Hassouni, \& Al Ibrahimi, 2020). Ketika semua itu telah berhasil diatasi maka pembelajaran aktif, kondusif dan menyenangkan dalam kelas dapat terwujud.

Pemanfaatan media simulasi PhET yang fleksibel dapat digunakan dengan berbagai strategi pembelajaran, masing-masing disesuaikan dengan tujuan yang hendak dicapai. Dikarenakan media simulasi PhET dapat diakses oleh siswa secara mandiri, maka strategi yang cocok untuk dikombinasikan dengan media simulasi $\mathrm{PhET}$ yaitu strategi pembelajaran yang berorientasi pada siswa. Hal ini dapat membuat siswa lebih aktif dalam kegiatan belajarnya sehingga menumbuhkan rasa ingin tahu siswa. Selain dapat mengonstruksi pengetahuannya secara mandiri, pembelajaran yang berorientasi pada siswa juga dapat membangun komunikasi yang baik kepada sesama siswa. Media simulasi PhET yang dapat diakses secara online oleh pendidik maupun peserta didik dapat digunakan tidak hanya dalam pembelajaran yang berlangsung di kelas tetapi juga pembelajaran yang berlangsung secara daring. Meski berbasis website, simulasi pada PhET tetap dapat diakses secara offline dengan cara mengunduh file simulasi terlebih dahulu melalui browser. Dalam kondisi pandemi Covid-19 menyebabkan pembelajaran dilakukan secara daring, sehingga media simulasi PhET ini cocok digunakan oleh guru untuk menampilkan beberapa fenomena fisika yang tidak dapat ditampilkan secara nyata ketika pembelajaran secara daring. Dengan demikian, penggunaan simulasi PhET dalam pembelajaran fisika telah terbukti menjadi cara yang efektif untuk menyajikan konsep-konsep abstrak melalui simulasi. 


\section{Kesimpulan}

Berdasarkan hasil kajian pustaka, penggunaan media simulasi PhET dapat diakses melalui tautan https://phet.colorado.edu, kemudian pengguna memilih materi yang akan disimulasikan. Penggunaan simulasi PhET akan lebih baik jika dikombinasikan dengan strategi pembelajaran yang berorientasi pada siswa. Dalam pembelajaran fisika media simulasi PhET efektif digunakan untuk menjelaskan konsep fisika yang bersifat abstrak. Adapun kelebihan dari simulasi PhET adalah mudah digunakan, fleksibel, memiliki tampilan yang menarik, mampu menampilkan fenomena yang sulit diamati secara langsung, serta memiliki akses gratis dan dapat diunduh secara offline. Sedangkan kekurangan dari simulasi PhET adalah perlunya perangkat elektronik untuk menjalankan simulasi dan perlunya penguasaan Information Communication and Technology (ICT) oleh guru.

\section{Daftar Pustaka}

Aprilia, R., Rustana, C. E., \& Budi, E. (2020). PENGARUH PEMANFAATAN MEDIA PHET DALAM PEMBELAJARAN JARAK JAUH MENGGUNAKAN WEBINAR ZOOM TERHADAP PENINGKATAN HIGH ORDER THINKING SKILLS (HOTS) SISWA FISIKA SMA. PROSIDING $\begin{array}{lllll}\text { SEMINAR NASIONAL } & \text { FISIKA }\end{array}$ https://doi.org/10.21009/03.SNF2020.02.PF.26

Azizaturredha, M., Fatmawati, S., \& Yuliani, H. (2019). PENERAPAN MODEL PEMBELAJARAN INKUIRI TERBIMBING DENGAN MEDIA LABORATORIUM VIRTUAL (PhET) UNTUK MENINGKATKAN HASIL BELAJAR, KETERAMPILAN PROSES SAINS DAN MINAT BELAJAR SISWA PADA POKOK BAHASAN ELASTISITAS. EduFisika, 4(01), 1-5. https://doi.org/10.22437/edufisika.v4i01.6051

Ben Ouahi, M., Ait Hou, M., Hassouni, T., \& Al Ibrahimi, E. M. (2020). Opinions of moroccan teachers towards the use of PhET simulations in teaching and learning physics - Chemistry. Colloquium in Information Science and Technology, CIST, 2020-June, 274-278. https://doi.org/10.1109/CiSt49399.2021.9357174

Bhakti, Y. B., Dwi, A. I. A., \& Dasmo. (2019). PENINGKATAN KOMPETENSI GURU MELALUI PELATIHAN PhET SIMULATION BAGI GURU MGMP FISIKA KABUPATEN SERANG. Jurnal Pengabdian Kepada Masyarakat, 3(2). Retrieved from http://dx.doi.org/10.30734/jabdipamas.v3i2.574

Dasmo, D., Budi Bhakti, Y., \& Napis, N. (2020). Pemanfaatan media pembelajaran Phet simulation dalam eksperimen fisika. Navigation Physics: Journal of Physics Education, 1(1), 18-21. https://doi.org/10.30998/npjpe.v1i1.192

Eveline, E., Jumadi, Wilujeng, I., \& Kuswanto, H. (2019). The Effect of Scaffolding Approach Assisted by PhET Simulation on Students' Conceptual Understanding and Students' Learning Independence in Physics. Journal of Physics: Conference Series, 1233(1). https://doi.org/10.1088/17426596/1233/1/012036

Ghivarianto, R. D. (2020). Digitalisasi Pendidikan, Nadiem Makarim Bicara Teknologi Perkuat Guru. Retrieved October 20, 2020, from news.detik.com website: https://news.detik.com/berita/d5000432/digitalisasi-pendidikan-nadiem-makarim-bicara-teknologi-perkuat-guru

Kuhltau, C. C. (2002). Teaching The Library Research. USA: Scarecrow Press Inc.

Laila, S. I. (2020). Keefektifan penerapan laboratorium virtual (PhET) Berbasis STEM dan keterampilan penyelesaian masalah. SEMINAR NASIONALF ISIKA (SNF) 2020, 4. Retrieved from https://fisika.fmipa.unesa.ac.id/proceedings/index.php/snf/article/view/140/136

Maulina, R. N., \& Kustijono, R. (2017). Efektifitas pembelajaran fisika berbantuan media virtual PhET disamping pelaksanaan lab riil untuk melatihkan keterampilan proses sains. Seminarnasionalfisika(Snf)2017, (November), 65-69. 
Muzana, S. R., Lubis, S. P. W., \& Wirda. (2021). Penggunaan Simulasi PhET terhadap Efektifitas Belajar IPA. Jurnal Dedikasi Pendidikan, 5(1), 227-236. Retrieved from http://jurnal.abulyatama.ac.id/index.php/dedikasi/article/download/1587/815

Perkins, K., Adams, W., Dubson, M., Finkelstein, N., Reid, S., Wieman, C., \& LeMaster, R. (2006). PhET: Interactive Simulations for Teaching and Learning Physics. The Physics Teacher, 44(1), 18-23. https://doi.org/10.1119/1.2150754

Ramadhan, A., Hasyim, F., \& Wibowo, H. A. C. (2019). EFEKTIFITAS PEMBELAJARAN FISIKA BAB GAYA MENGGUNAKAN MEDIA SIMULASI PhET DAN ALAT PERAGA SEDERHANA PADA SISWA SMP KELAS 8 UNTUK MENINGKATKAN PENGUASAAN MATERI. Prosiding Seminar Nasional Pendidikan Fisika, 4(1), 2527-5917. Retrieved from https://jurnal.unej.ac.id/index.php/fkipepro/article/view/15151

Santoso, H. (2009). PENGARUH PENGGUNAAN LABORATORIUM RIIL DAN LABORATORIUM VIRTUIL PADA PEMBELAJARAN FISIKA DITINJAU DARI KEMAMPUAN BERPIKIR KRITIS SISWA. Retrieved from https://eprints.uns.ac.id/5203/1/130910508201004201.pdf

Sari, E., Khairani, D., Subchi, I., Durachman, Y., Rifai, A., \& Rosyada, D. (2021). Application of PhET Simulation Media in Physics Learning During a Pandemic Covid-19. Proceedings of the 3rd International Colloquium on Interdisciplinary Islamic Studies, ICIIS 2020, $20-21$ October 2020, Jakarta, Indonesia. EAI. https://doi.org/10.4108/eai.20-10-2020.2305146

Sugiyono. (2010). Metode Penelitian Kuantitatif dan Kualitatif dan R\&D. Bandung: ALFABETA. 